\title{
Biological Risks from Long-Term Storage of Wood Chips
}

\section{Martin Lieskovský1, Miloš Gejdoš1*,Valéria Messingerová1, Miroslav Němec², Zuzana Danihelová ${ }^{3}$, Veronika Moravčíková ${ }^{1}$}

\author{
${ }^{1}$ Technical University in Zvolen, Faculty of Forestry, Department of Forest Harvesting, Logistics and Ameliorations, \\ T. G. Masaryka 24, Zvolen 960 53, Slovakia \\ ${ }^{2}$ Technical University in Zvolen, Faculty of Wood Sciences and Technology, Department of Physics, \\ Electrical Engineering and Applied Mechanics, T.G. Masaryka 24, Zvolen 960 53, Slovakia \\ ${ }^{3}$ Technical University in Zvolen, Institute of Foreign Languages, \\ T. G. Masaryka 24, Zvolen 960 53, Slovakia
}

Received: 27 March 2017

Accepted: 22 April 2017

\begin{abstract}
The aim of our study was to monitor and analyze the main biological hazards connected to the long-term storage of wood chips for energy production. The analysis was carried out in four high-capacity storage yards of the town heating plants in the Banská Bystrica self-governing region in Slovakia. Five samples were taken from each pile of a rectangular shape and volume over $4,000 \mathrm{~m}^{3}$; the sampling was carried out at the beginning of the monitoring period and at the end of the monitoring period (after one year). Thirtyfour species of microscopic fungi were identified (18 at the beginning of the monitoring period and 16 at the end of the monitoring period). Thirty-three of them can potentially cause severe diseases. Fungi of the genus Aspergillus, causing severe diseases, were identified as the most abundant. The research confirmed that if the length of storage time is more than a year, the potential hazards for human health increase due to the increasing number of spore-forming pathogens. Following the monitoring of atmospheric conditions the highest increase of harmful spores was recorded at the average annual temperature of $10^{\circ} \mathrm{C}$ and precipitation of over $1,000 \mathrm{~mm}$ a year.
\end{abstract}

Keywords: wood chips, fungal activity, long-term storage, biomass, biological risks

\section{Introduction}

Renewable energy sources based on wood are becoming increasingly important and popular. However, their increased consumption is inevitably connected with questioning their quality [1-2]. Quality is in specific cases determined by the method of production and the

*e-mail: gejdos@tuzvo.sk storage process [3-4]. The quality of wood chips is at present evaluated according to the calorific value and moisture content, which are often influenced, besides the wood species itself, by weather conditions and storage method [5-9]. The increased number of plants using wood chips as a source of energy is connected with raising the question of health and safety hazards associated with the production and storage of wood chips. The factors most hazardous for human health are represented by the hazards associated with the activity of fungi and moulds in 
the stored wood chips, and inhalation of wood dust when manipulating them [10-13]. These hazards are caused by the course of biological processes in the stored material [14]. It was discovered that the amount of spores in the air during manipulation of wood chips will decrease below the value of 1,000 CFU. $\mathrm{m}^{-3}$ (colony forming unit. $\mathrm{m}^{-3}$ ) only at a distance of $300 \mathrm{~m}$ from the pile. This can therefore be considered dangerous and potentially harmful to human health [15].

Town heating plants in Slovakia usually store wood chips in high-capacity piles (over $1 \mathrm{t}$ ), which are freely stored and thus exposed to atmospheric conditions [1]. The supply and transfer of the raw material to and from such piles is not usually continual. The storage yards and the heating plants are very often situated in the residential areas of towns and cities. This method of storing the material intensifies the risk of creating harmful fungi and moulds even more [16-17]. Employees and residents living in the direct vicinity of the heating plants are not adequately informed about the hazards connected to biomass storage. There is also a lack of legislation and regulation possibilities in order to eliminate such hazards and their impact on human health.

The aim of the study was to monitor and analyze the main biological hazards (activity of fungi and moulds) connected to the long-term storage of wood chips for energy production during a period longer than a year. The analysis was carried out using material from four long-term storage yards of wood chips in town heating plants having their storage yards in the residential areas of towns in Slovakia. Weather development at the storage sites was monitored as well (average daytime temperature and atmospheric precipitation). The samples which were used to identify the hazards were taken at the beginning and at the end of the monitoring period. Information on biological hazards, posing a risk to the health of employees and residents living in the vicinity of the heating plants, are important mainly for further development of this branch, and legislative regulations and sanctions in order to protect human health.

\section{Material and Methods}

\section{Material and Experimental Piles}

Four high-capacity storage yards of town heating plants in the Banská Bystrica self-governing region in Slovakia (in the radius of $65 \mathrm{~km}$ ) were selected for sampling (GPS coordinates: No. 1 storage 48 $34^{\prime} 52.4^{\prime \prime} \mathrm{N}$ 19³1'37.6'E; No. 2 storage 48 34'33.1'N 1957'28.7'"E; No 3 storage $48^{\circ} 40^{\prime} 44.0^{\prime \prime} \mathrm{N} 20^{\circ} 07^{\prime} 22.4^{\prime \prime} \mathrm{E}$; and No. 4 storage $\left.48^{\circ} 25^{\prime} 33.7^{\prime \prime} \mathrm{N}, 1^{\circ} 47^{\prime} 33.7^{\prime \prime} \mathrm{E}\right)$. All yards, as well as the heating plants, were situated in the residential areas (number of inhabitants from 5,772 to 12,696). The woodchip piles were created in March and April 2015 and the first sampling in all storage yards was carried out on 29 October 2015 (the storage time was longer than six months for all piles). The second sampling in all storage yards was carried out on 28 October 2016. None of the storage yards was covered; they were situated in open space and the piles were made of woodchips freely poured onto concrete and on a sunny place. The piles consisted of woodchips for energy purposes made of a blend of $80 \%$ beech and $20 \%$ spruce and fir. The surface and volume of the piles were determined according to a $3 \mathrm{D}$ model. In order to create this model an unmanned drone DJI Phantom 3 Professional with a built-in camera with resolution of 4,000 x 3,000 pixels was used. Geodetic ranging poles were used to determine the scale. Agisoft PhotoScan Professional software was used to determine the volume and surface of the woodchip piles [18-19].

\section{Sampling Technique}

Five samples were taken from each pile during two sampling periods - October 2015 and 2016 (40 samples altogether) for analysis. Three samples were sampled from the surface of each pile and two from a depth of $0.5 \mathrm{~m}$. Experimental piles had a rectangular ground plan. The tested piles and locations of the sampling points are illustrated in Fig. 1.

The samples were sampled using a shovel and the volume the each sample was 21 . Each sample was stored in a hermetically sealable plastic bag with a specific number.

\section{Weather Conditions}

Temperature and precipitation were measured using a net of weather stations in the towns where the experimental piles were located. The temperature was measured three times a day at 07:00, 14:00, and 21:00. These data were then used to calculate the average daytime temperature. The precipitation was measured using a rain gauge. The measured values are shown in Fig. 2. The temperatures

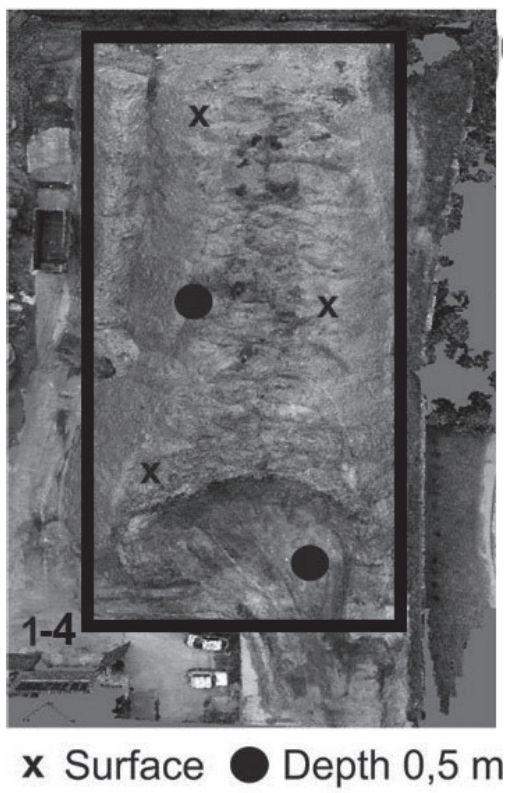

Fig. 1. Woodchip storage area Nos. 1-4 and sampling points. 

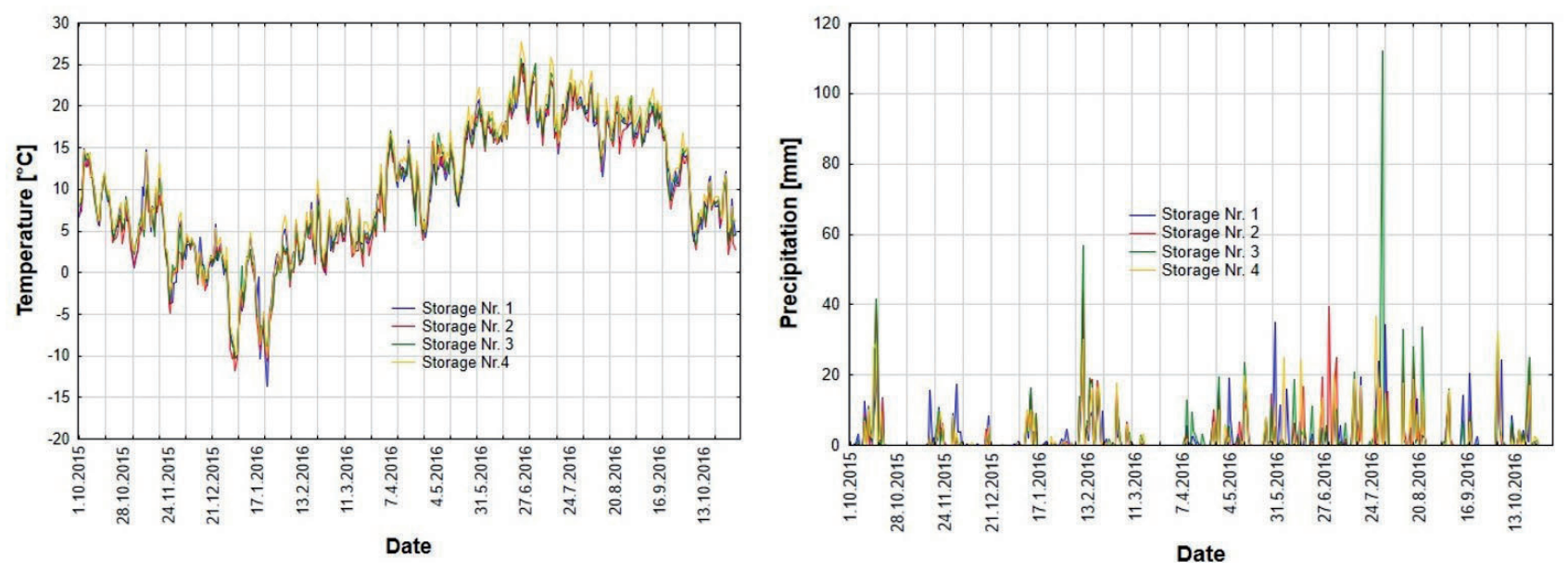

Fig. 2. Ambient temperature and precipitation during the storage period.

were approximately the same at all locations and the difference in the average year temperature was a maximum of $1^{\circ} \mathrm{C}$. Regarding precipitation, the overall amount of precipitation during the monitoring period in towns 1 , 2 , and 4 was in the interval $\pm 102 \mathrm{~mm}$. Town 3 was an exception, since the recorded amount of precipitation was $275 \mathrm{~mm}$ more than in town 4, which had the lowest number recorded.

\section{Laboratory Analyses}

Microbiological identification of fungi in samples was performed by examination $[2,20]$ in the accredited laboratory of the Regional Public Health Authority in Poprad.

For the qualitative determination of microscopic fungi we used culturing on agar medium. A homogenized sample of $20 \mathrm{~g}$ was added to $180 \mathrm{~mL}$ of sterile water containing $0.02 \%$ of polyoxyethylene (20) sorbitan monooleate (Tween 80 ). For a more precise release of microorganisms from the material, the sample was shaken on a horizontal shaker for $30 \mathrm{~min}$. For the inoculation of wort agar we used dilutions of $10^{-1}$ to $10^{-4}$ in three repetitions. The wort agar was composed of $1,000 \mathrm{~mL}$ of beer wort, $20 \mathrm{~g}$ of agar, and 1,000 $\mathrm{mL}$ of distilled water. Agar plates were cultivated at $25^{\circ} \mathrm{C} \pm 1^{\circ} \mathrm{C}$ for 5-7 days. After obtaining pure microscopic cultures, their identification was performed based on morphological and cultural characteristics according to the guides listed in the literature [12, 21-22].

For identifying and isolating the microscopic fungi, cultures created on agar were used. Isolates were inoculated to the cultivating medium. The following cultivating media were used for identification: czapek yeasts extract agar (CYA), malt extract agar (MEA), creatine sucrose agar (CREA), and czapek yeasts extract agar with 20\% sucrose (CY20S). The identification of isolates was carried out according to $[12,23]$.

When studying the colonies we observed the following features:

- Cultivation features on the identification agars (shape and size of the colony, speed of colony growth, colony colour, production of exudates on the colony surface, and production and excretion of pigments into the environment).

- Micromorphologic features in the mounts with lactoferrin (occurrence of asexual spores, their size, shape, method of creation and arrangement; type of vegetative fructification structure, its arrangement and shape; occurrence of special structures; occurrence of sexual fructification structures and spores, their size, shape and arrangement).

The results were in the form of occurrence frequency, relative density, and quantitative occurrence of microscopic fungi. The frequency of occurrence $(\mathrm{Fr})$ and relative density $(R D)$ of the species and genera of the microscopic fungi is calculated according to the following relationships [24]:

$$
\begin{aligned}
& F r=(n s / N) \times 100[\%] \\
& R D=(n i / N I) \times 100[\%]
\end{aligned}
$$

...where:

$\mathrm{Fr}$ - frequency of occurrence

$R D$ - relative density

$n s$ - the number of samples in which the genus or species was detected

$N$ - total number of samples

$N I$ - total number of isolates

$n i-$ number of isolates of the given genus or species

In order to find out the number of microscopic fungi in $1 \mathrm{~g}$, i.e., to find out the colonies comprising a unit (CFU.g $\left.{ }^{-1}\right)$ that were isolated, Petri dishes from two dilutions one after another, consisting of a maximum of 150 colonies were used. In order to determine the number of microscopic fungi $\mathrm{CFU}$ in $1 \mathrm{~g}$, the following relationship was used [25]:

$$
N=\frac{\sum c}{V \cdot\left[\left(n_{1}+0.1 . n_{2}\right) d\right]}\left[\mathrm{CFU} \cdot \mathrm{g}^{-1}\right]
$$


Table 1. Identified fungal biological risks in storage piles.

\begin{tabular}{|c|c|c|c|c|c|}
\hline \multicolumn{3}{|c|}{$\begin{array}{l}\text { Storage Pile No./ } \\
\text { Area/Volume }\end{array}$} & \multirow{2}{*}{$\begin{array}{l}\text { Sample } \\
\text { No./ } \\
\text { sampling } \\
\text { point }\end{array}$} & \multirow{2}{*}{$\begin{array}{c}\text { Identified microorganisms } \\
29.10 .2015 \\
\text { Aspergillus sp., Fusarium oxysporum, Fusarium } \\
\text { nivale, Cladosporium cladosporioides, Aspergillus } \\
\text { flavus, Mucor racemosus, Aspergillus brasiliensis, } \\
\text { Pantoea }\end{array}$} & \multirow{2}{*}{$\begin{array}{l}\text { Identified microorganisms } \\
28.10 .2016 \\
\text { Aspergillus wentii, Aspergillus brasil- } \\
\text { iensis, Mucor sp., Aspergillus sp., } \\
\text { Alternaria alternata }\end{array}$} \\
\hline \multirow{5}{*}{1} & \multirow{5}{*}{$\begin{array}{c}2,002 \\
\mathrm{~m}^{2}\end{array}$} & \multirow{5}{*}{$\begin{array}{c}4,713 \\
\mathrm{~m}^{3}\end{array}$} & & & \\
\hline & & & $\begin{array}{l}2 / 0.5 \mathrm{~m} \\
\text { depth }\end{array}$ & $\begin{array}{c}\text { Aspergillus brasiliensis, Aspergillus flavus, Aspergillus } \\
\text { sp., Mucor spinosus, Pantoea }\end{array}$ & Aspergillus sp. \\
\hline & & & $3 /$ surface & $\begin{array}{c}\text { Mucor spinosus, Aspergillus Flavus, Fusarium } \\
\text { oxysporum, Aspergillus brasiliensis, Aspergillus sp., } \\
\text { Pantoea }\end{array}$ & $\begin{array}{c}\text { Cladosporium cladosporioides, } \\
\text { Aspergillus sp., Aspergillus fumigatus, } \\
\text { Mycelia sterilia }\end{array}$ \\
\hline & & & 4 / surface & $\begin{array}{c}\text { Aspergillus brasiliensis, Aspergillus flavus, Aspergil- } \\
\text { lus sp., Cladosporium cladosporioides, Fusarium } \\
\text { oxysporum, Pantoea }\end{array}$ & Aspergillus sp., Aspergillus fumigatus \\
\hline & & & $\begin{array}{l}5 / 0.5 \mathrm{~m} \\
\text { depth }\end{array}$ & Aspergillus flavus, Aspergillus sp., Eurotium sp. & $\begin{array}{l}\text { Aspergillus flavus, Aspergillus fumiga- } \\
\text { tus, Mucor spinosus }\end{array}$ \\
\hline \multirow{5}{*}{2} & \multirow{5}{*}{$\begin{array}{c}1,984 \\
\mathrm{~m}^{2}\end{array}$} & \multirow{5}{*}{$\begin{array}{c}4,989 \\
\mathrm{~m}^{3}\end{array}$} & $6 /$ surface & $\begin{array}{l}\text { Trichoderma koningii, Cladosporium cladosporioides, } \\
\text { Aspergillus brasiliensis, Aspergillus flavus, Eurotium } \\
\text { sp., Aspergillus sp., Mucor racemosus, Pantoea }\end{array}$ & $\begin{array}{c}\text { Fusarium sp., Aspergillus brasiliensis, } \\
\text { Aspergillus sp., Aspergillus flavus, } \\
\text { Fusarium oxysporum }\end{array}$ \\
\hline & & & $7 /$ surface & $\begin{array}{c}\text { Aspergillus flavus, Aspergillus sp., Fusarium nivale, } \\
\text { Mucor hiemalis, Pantoea }\end{array}$ & $\begin{array}{l}\text { Aspergillus sp., Cladosporium clado- } \\
\text { sporioides, Cladosporium herbarum }\end{array}$ \\
\hline & & & $8 /$ surface & $\begin{array}{c}\text { Eurotium sp., Aspergillus brasiliensis, Mucor hiema- } \\
\text { lis, Aspergillus sp., Pantoea }\end{array}$ & $\begin{array}{c}\text { Aspergillus sp., Cladosporium herba- } \\
\text { rum, Mycelia sterilia }\end{array}$ \\
\hline & & & $\begin{array}{l}9 / 0.5 \mathrm{~m} \\
\text { depth }\end{array}$ & $\begin{array}{c}\text { Trichoderma koningii, Trichoderma viride, Aspergillus } \\
\text { brasiliensis, Aspergillus sp., Aspergillus flavus, Mucor } \\
\text { spinosus, Fusarium oxysporum, Pantoea }\end{array}$ & $\begin{array}{c}\text { Aspergillus brasiliensis, Cladospo- } \\
\text { rium cladosporioides, Aspergillus sp., } \\
\text { Mucor hiemalis }\end{array}$ \\
\hline & & & $\begin{array}{l}10 / 0.5 \mathrm{~m} \\
\text { depth }\end{array}$ & $\begin{array}{l}\text { Aspergillus brasiliensis, Eurotium sp., Mucor spino- } \\
\text { sus, Pantoea }\end{array}$ & - \\
\hline \multirow{5}{*}{3} & \multirow{5}{*}{$\begin{array}{l}1,754 \\
\mathrm{~m}^{2}\end{array}$} & \multirow{5}{*}{$\begin{array}{c}4,596 \\
\mathrm{~m}^{3}\end{array}$} & $\begin{array}{l}11 / 0.5 \mathrm{~m} \\
\text { depth }\end{array}$ & Eurotium sp., Mucor spinosus, Aspergillus brasiliensis & $\begin{array}{l}\text { Mycelia sterilia, Aspergillus ochra- } \\
\text { ceus, Aspergillus brasiliensis, Asper- } \\
\text { gillus sp., Mucor sp. }\end{array}$ \\
\hline & & & $\begin{array}{l}12 / \text { sur- } \\
\text { face }\end{array}$ & Aspergillus brasiliensis, Aspergillus flavus & Aspergillus sp. \\
\hline & & & $\begin{array}{l}13 \text { / sur- } \\
\text { face }\end{array}$ & $\begin{array}{c}\text { Rhizopus arrhizus, Geotrichum candidum, Aspergillus } \\
\text { brasiliensis }\end{array}$ & $\begin{array}{l}\text { Trichoderma viride, Aspergillus sp., } \\
\text { Mycelia sterilia }\end{array}$ \\
\hline & & & $\begin{array}{l}14 / \text { sur- } \\
\text { face }\end{array}$ & Rhizopus arrhizus, Aspergillus brasiliensis & $\begin{array}{l}\text { Aspergillus brasiliensis, Aspergillus } \\
\text { sp., Cladosporium herbarum }\end{array}$ \\
\hline & & & $\begin{array}{l}15 / 0.5 \mathrm{~m} \\
\text { depth }\end{array}$ & $\begin{array}{l}\text { Geotrichum candidum, Rhizopus arrhizus, Rhizopus } \\
\text { nigricans }\end{array}$ & $\begin{array}{c}\text { Aspergillus ochraceus, Aspergillus } \\
\text { brasiliensis }\end{array}$ \\
\hline \multirow{5}{*}{4} & \multirow{5}{*}{$\begin{array}{c}2,310 \\
\mathrm{~m}^{2}\end{array}$} & \multirow{5}{*}{$\begin{array}{c}4,242 \\
\mathrm{~m}^{3}\end{array}$} & $\begin{array}{l}16 / 0.5 \mathrm{~m} \\
\text { depth }\end{array}$ & Aspergillus brasiliensis, Geotrichum candidum & $\begin{array}{c}\text { Aspergillus brasiliensis, Aspergillus } \\
\text { sp. }\end{array}$ \\
\hline & & & $\begin{array}{l}17 / \text { sur- } \\
\text { face }\end{array}$ & $\begin{array}{l}\text { Geotrichum candidum, Aspergillus brasiliensis, Rhizo- } \\
\text { pus arrhizus, Mucor spinosus }\end{array}$ & $\begin{array}{l}\text { Mycelia sterilia, Mucor hiemalis, } \\
\text { Cladosporium herbarum, Cladospo- } \\
\text { rium cladosporioides, Aspergillus } \\
\text { brasiliensis, Aspergillus sp. }\end{array}$ \\
\hline & & & $\begin{array}{l}18 / 0.5 \mathrm{~m} \\
\text { depth }\end{array}$ & $\begin{array}{l}\text { Geotrichum candidum, Aspergillus brasiliensis, Rhizo- } \\
\text { pus nigricans, Eurotium sp. }\end{array}$ & $\begin{array}{l}\text { Mycelia sterilia, Cladosporium herba- } \\
\text { rum, Aspergillus sp., Mucor hiemalis }\end{array}$ \\
\hline & & & $\begin{array}{l}19 / \text { sur- } \\
\text { face }\end{array}$ & $\begin{array}{c}\text { Mucor spinosus, Geotrichum candidum, Rhizopus } \\
\text { nigricans }\end{array}$ & $\begin{array}{l}\text { Aspergillus ochraceus, Aspergillus } \\
\text { sp., Cladosporium cladosporioides, } \\
\text { Fusarium oxysporum }\end{array}$ \\
\hline & & & $\begin{array}{l}20 / \text { sur- } \\
\text { face }\end{array}$ & Mucor spinosus, Geotrichum candidum & $\begin{array}{l}\text { Mucor hiemalis, Alternaria alter- } \\
\text { nata, Cladosporium cladosporioides, } \\
\text { Aspergillus ochraceus, Aspergillus } \\
\text { fumigatus, Aspergillus brasiliensis }\end{array}$ \\
\hline
\end{tabular}


...where:

$\Sigma c$-sum of characteristic colonies on selected dishes used for calculation

$n_{1}$ - number of dishes of first dilution used to calculate

$n_{2}$ - number of dishes of second dilution used to calculate

$d$-dilution factor is identical to the first dilution used

$V$ - volume of inoculum used for the inoculation of cultivating medium

The quantification of fungi was analyzed according to the standard [25]. Rounding off the number of CFU was in accordance with [26].

\section{Results and Discussion}

\section{Results}

Table 1 illustrates the results of microscopic fungi (mould) identification in individual samples, including the pile characteristics from which they were sampled. The first analysis (10 October 2015): in each sample at least two species of fungi were identified. In sample Nos. 1 to 10 (storage yards 1 and 2) aerobic spore-forming bacteria were identified as well. Yeasts were identified altogether in 13 samples. After a repeated sampling after one year (28 October 2016) the spores of fungi and moulds were not identified in one sample from a depth of $0.5 \mathrm{~m}$ on storage yard No. 2. Yeasts were identified in 18 out of 20 samples.

The most often identified species were: Aspergillus brasiliensis (in 15 samples at the first sampling and in nine samples taken after one year); yeasts were identified in 13 samples (in 18 samples taken after one year); Aspergillus flavus (in nine samples at the first sampling and in two samples taken after one year), Mucor spinosus (in eight samples at the first sampling and in one sample taken after one year); spores of the genus Aspergillus were identified in nine samples at the time first sampling and in 15 samples taken after one year. The least often occurring species were Trichoderma viride, Trichoderma koningii, Aspergillus wentii, Mycelia sterilia, Cladosporium herbarum, Mucor racemosus, Mucor hiemalis, and Fusarium nivale. The overview of the individual species from the overall number of samples is illustrated in Fig. 3. The same species of fungal and mould spores in both samplings (initial and after one year) were identified in nine cases altogether.

Table 2 illustrates the results of quantification of the individual toxigenic micromycetes (moulds). In the first two storage yards the maximum numbers of colonies were quantified in surface sample Nos. 4 and 6. A high number of colonies also was recorded in samples taken from $0.5 \mathrm{~m}$ depth. In storage yard Nos. 3 and 4 the highest number of colonies of identified fungi and moulds was quantified in the samples taken from a depth of $0.5 \mathrm{~m}$.

The acquired results confirm that the point of sampling does not influence the intensity of occurrence of healththreatening fungi and moulds significantly. Nor in the case of bigger piles does it significantly influence the occurrence of toxigenic micromycetes at the shallower depth of $0.5 \mathrm{~m}$.

After repeated sampling, the concentration of spores in the samples was much higher (Table 2). On average, the concentration in the samples from all four locations increased by 456,907 CFU.g ${ }^{-1}$. This result confirms that increased storage period also increases the risk of being infected by pathogenic spores due to their higher concentrations. The same or even higher number of fungal and mould species was recorded at the second sampling in all storage yards, except storage yard No. 2, where the second sampling confirmed seven fewer species.

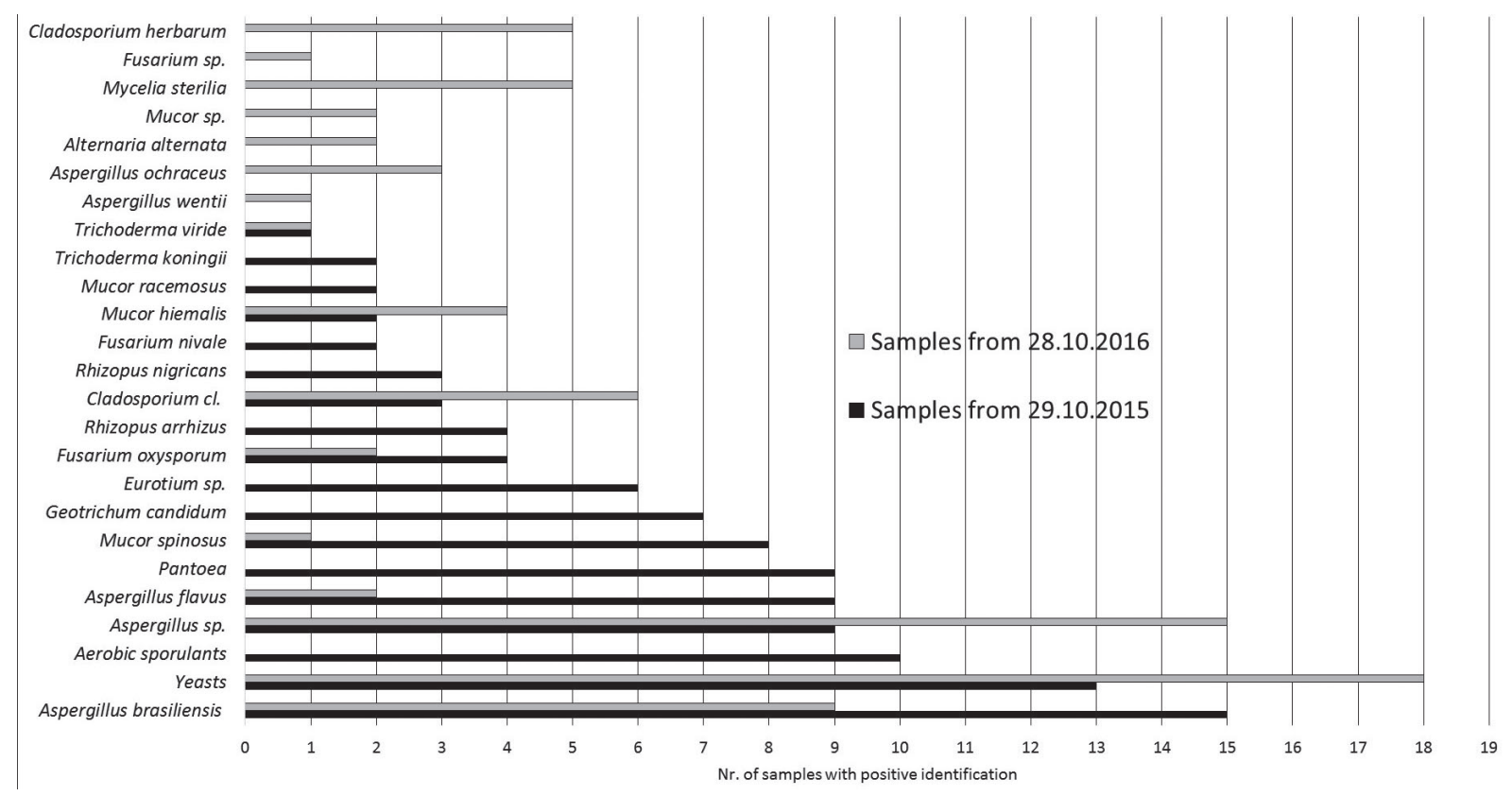

Fig. 3. Number of samples with positive identification of individual species. 
Table 2. Quantification of potential toxigenic micromycetes (moulds) in samples.

\begin{tabular}{|c|c|c|c|}
\hline $\begin{array}{l}\text { Storage } \\
\text { No. }\end{array}$ & $\begin{array}{c}\text { Sample No. / } \\
\text { sampling point }\end{array}$ & $\begin{array}{l}N\left[\mathrm{CFU} . \mathrm{g}^{-1}\right] \\
29.10 .2015\end{array}$ & $\begin{array}{l}N\left[\mathrm{CFU} . \mathrm{g}^{-1}\right] \\
28.10 .2016\end{array}$ \\
\hline \multirow{5}{*}{1} & $1 /$ surface & 1,800 & 180,000 \\
\hline & $2 / 0.5 \mathrm{~m}$ depth & 34,000 & 340,000 \\
\hline & $3 /$ surface & 930 & 5,900 \\
\hline & 4 / surface & $>75,000$ & 64,000 \\
\hline & $5 / 0.5 \mathrm{~m}$ depth & 36,000 & 25,000 \\
\hline \multirow{5}{*}{2} & $6 /$ surface & $>75,000$ & 490,000 \\
\hline & 7 / surface & 37,000 & 7,700 \\
\hline & $8 /$ surface & 32,000 & 49,000 \\
\hline & $9 / 0.5 \mathrm{~m}$ depth & 40,000 & 85,000 \\
\hline & $10 / 0.5 \mathrm{~m}$ depth & 31,000 & $<50$ \\
\hline \multirow{5}{*}{3} & $11 / 0.5 \mathrm{~m}$ depth & 29,000 & 240,000 \\
\hline & 12 / surface & 28,000 & 100 \\
\hline & 13 / surface & 2,700 & 110,000 \\
\hline & 14 / surface & 7,800 & 320,000 \\
\hline & $15 / 0.5 \mathrm{~m}$ depth & 35,000 & 120,000 \\
\hline \multirow{5}{*}{4} & $16 / 0.5 \mathrm{~m}$ depth & 36,000 & 1,300 \\
\hline & 17 / surface & 1,900 & 31,000 \\
\hline & $18 / 0.5 \mathrm{~m}$ depth & 25,000 & 1,200 \\
\hline & $19 /$ surface & 890 & 49,000 \\
\hline & 20 / surface & 2,600 & 240,000 \\
\hline
\end{tabular}

The statistical analysis of the development of atmospheric temperature and the amount of precipitation also confirmed the impact of these parameters on the development and amount of pathogens being identified. Following the sampling carried out after one year of storage it can be concluded that the highest concentration of pathogenic and mould spores was linked to the average annual temperature of $10^{\circ} \mathrm{C}$, and precipitation at the average level of 1,000 mm per year (Fig. 4).

\section{Discussion}

Fungi of the genus Aspergillus were identified as the most numerous. Some Aspergillus species cause diseased grain crops, especially maize and synthesize mycotoxins, including aflatoxin [27]. Aspergillus brasiliensis is less likely to cause human disease than some other Aspergillus species, but if large amounts of spores are inhaled, a serious lung disease, aspergillosis, can occur. Aspergillosis occurs worldwide. The disease manifests itself most often in the disseminated pulmonary form or lung aspergiloma. Besides the lower respiratory tract, paranasal sinuses, eyes, CNS, and myocardium can be affected as well. Similarly high numbers of colonies of these species also

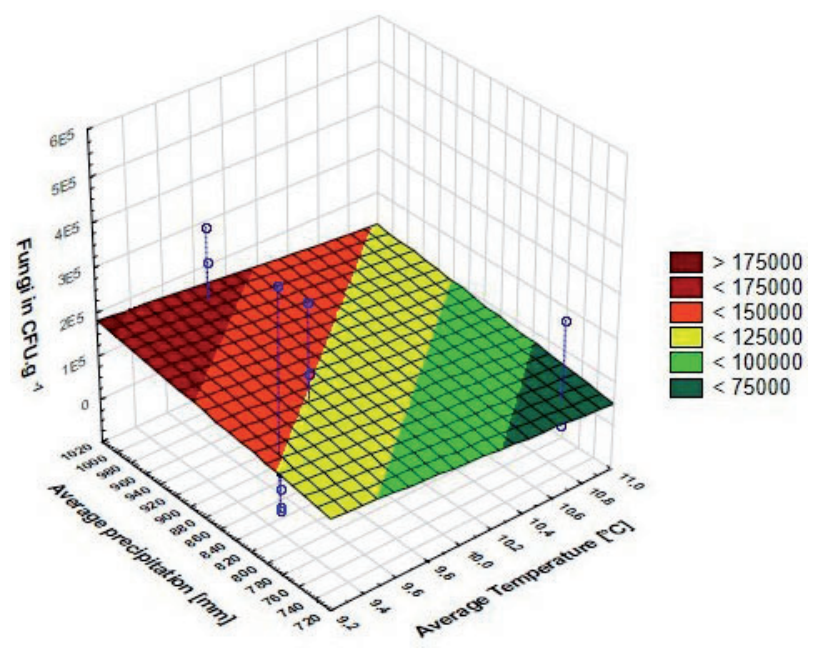

Fig. 4. Occurrence of fungi spores depending on air temperature and precipitation

were identified in other studies describing shorter storage times $[2,28]$. When manipulating wood chips quite high concentrations of the Aspergillus species in the air were recorded in other studies [29-30]. The spores of genus Aspergillus also were identified as the most numerous in willow biomass in heating plants of Poland (in $51.1 \%$ of sample content) [31-32] and also at workplaces for the production of forest biomass (wood chips, in 33-95\% sample content) [33]. In Danish biofuel plants the spores of Aspergillus fumigatus in average concentration $2.48 \mathrm{x}$ $10^{4}$ CFU.g. ${ }^{-1}$ were identified [34].

In general, thermotolerant fungi and thermophilic actinobacteria were more abundant in the wood chips and bark. Mixtures of fuels also seemed to be very susceptible to microbial growth. Actinobacteria, Aspergillus fumigatus, Penicillium sp., and yeasts were the most common identified species in the study from Finland [35]. Microbial concentrations during unloading were higher than $10^{4}$ CFU.m ${ }^{-3}$, which may pose a threat to worker health.

Fusarium oxysporum identified in four samples is known as a producer of mycotoxins T-2 toxin, sambutoxin, FUS X, FUS C, MON, and NIV. The most common diseases caused by this species are keratitis, onychomycosis, and hyalohyphomycosis [36-37]. The less frequent occurrence of the genus Fusarium was identified also in other studies $[2,15,38]$. In the study on birch and spruce wood from Finland, the spores of genus Fusarium and Trichoderma were identified as well. A slightly higher share of fungal growth was observed on plates of birch wood samples stored uncovered (94 and 100\% after the first and second weeks of incubation, respectively) compared to uncovered spruce samples (78 and $83 \%$ after the first and second weeks) [39].

Alternaria species are known as major plant pathogens. They are also common allergens in humans, growing indoors and causing hay fever or hypersensitive reactions that sometimes lead to asthma. They readily cause opportunistic infections in immunocompromised 
people [40]. Alternaria alternata is capable of producing tenuazonic acid and other toxic metabolites that may be associated with disease in humans or animals [41].

A high occurrence also was recorded in the case of aerobic spore-forming bacteria, yeasts, and genus Pantoea. Aerobic spore-forming bacteria are bacteria of the genus Bacillus causing infectious diseases of the digestive system. The yeasts usually cause candidiasis, and the bacteria of the genus Pantoea cause various infections (e.g., septic arthritis and knee joint inflammation) [42]. The occurrence of these dangerous bacteria in such amounts associated with shorter storage times has not been discussed in any studies published so far.

\section{Conclusions}

Information on the health hazards during the production, manipulation, and storage of the wood ships are not sufficient. The employees are often poorly informed about the potential health hazards, and they are not provided with personal protective equipment. There is also a lack of relevant legislation that would deal with locating the high-capacity storage yards in the residential areas, monitoring the biological hazards and possible sanctions due to the health threats.

When evaluating the influence of microscopic fungi on the employees manipulating wood chips for energy purposes, it is important to consider not only the number of fungi but also the specific species. From the overall number of 25 identified microscopic fungi, 24 species pose a risk to human health and can cause various diseases. Particularly dangerous are the species Aspergillus, Mucor, and Rhizopus. They cause several diseases described as examples of the most aggressive mycotic infections with a high mortality rate [36, 43-45]. Besides these infectious species, species with a high toxicity also were identified in the piles. Genera Aspergillus, Fusarium, and Trichoderma are very often described as the most important toxigenic microscopic fungi-producing carcinogenic mycotoxins (alfatoxin B1 and B2, ochratoxin A, and fumonisin) [46-48]. Aspergillus niger has a rich history of being used at the industrial scale in fermentations, and now in biomass degradation, and as being "generally regarded as safe" (GRAS) by the United States Food and Drug Administration (FDA) [49-50]. In addition, Mucor sp. and Fusarium sp. are associated with serious illnesses [51].

The study confirmed that storage time longer than a year poses a high risk of being infected due to biologically harmful factors. Extending the storage time does not decrease the health hazards. Although after one year of storage the number of identified species was two species fewer, the quantity of spores in CFU. $\mathrm{g}^{-1}$ increased in all storage yards. The employees work in hazardous conditions, and especially those suffering from some kind of immunodeficiency should be informed in detail about these hazards and provided with quality personal protective equipment. It is also important to determine safe work procedures and length of storage time in order to minimize health risks. Regarding the high-capacity storage yards in the residential areas, it is important to carry out further structural modifications in order to isolate the yards and minimize health risks for residents living in the vicinity [52-53].

The obtained results point at the high degree of danger to human health when manipulating wood chips. Within one region (radius of $65 \mathrm{~km}$ ) no significant impact of a wood chip storage yard on the occurrence of harmful pathogens and their number was proven. The highest occurrence of spores of pathogenic fungi was recorded in the storage yard with the highest amount of average annual precipitation. On the other hand, the lowest occurrence of spores was recorded on the yard with the lowest amount of annual precipitation. The results are useful mainly from the point of view of awareness of employees and residents of the areas in question and can serve as a tool to determine the basic legislative frameworks for improving the environment [54].

\section{Acknowledgements}

The research described in this paper was financed jointly by KEGA - the Cultural and Education Agency of the Ministry of Education, Science, Research, and Sport of the Slovak Republic and Slovak Academy of Sciences (project Nos. 003TU Z-4/2015 and 013TU Z-4/2017).

\section{References}

1. GEJDOŠ M., LIESKOVSKÝ M., SLANČÍK M., NĚMEC M., DANIHELOVÁ Z. Storage and Fuel Quality of Coniferous Wood Chips. Bioresources 10 (3), 5544, 2015.

2. SUCHOMEL J., BELANOVÁ K., GEJDOŠ M., NĚMEC M., DANIHELOVÁ A., MAŠKOVÁ Z. Analysis of Fungi in Wood Chip Storage Piles. Bioresources 9 (3), 4410, 2014.

3. CAVALLI R., GRIGOLATO S. Influence of characteristics and extension of a forest road network on the supply cost of forest woodchips. J. For. Res.-JPN 15 (3), 202, 2010.

4. SCHWEIER J., SCHNITZLER J.P., BECKER G. Selected environmental impacts of the technical production of wood chips from poplar short rotation coppice on marginal land. Biomass Bioenerg. 85, 235, 2016.

5. BRAND M.A., DE MUNIZ G.I.B., QUIRINO W.F., BRITO J.O. Influence of storage time on the quality of biomass for energy production in humid subtropical regions. Cerne $\mathbf{1 6}$ (4), 531, 2010.

6. BARONTINI M., SCARFONE A., SPINELLI R., GALLUCCI, F. Storage dynamics and fuel quality of poplar chips. Biomass and Bioenergy 62, 17, ISSN: 0961-9534, 2014.

7. AFZAL M.T., BEDANE A.H., SKOHANSANJ S., MAHMOOD W. Storage of comminuted and uncomminuted forest biomass and its effect on fuel quality. Bioresources 5 (1), 55 ISSN: 1930-2126, 2010.

8. STOLARSKI M.J., KRZYŻANIAK M., WARMIŃSKI K., TWORKOWSKI J., SZCZUKOWSKI S. Willow Biomass Energy Generation Efficiency and Greenhouse Gas Reduction Potential. Pol. J. Environ. Stud. 24 (6), 2627, 2015. 
9. LENZ H., PECENKA R., IDLER CH., DUMFORT S., WHITTAKER C., AMMON CH., HARTUNG E. Continuous weighing of a pile of poplar wood chips - A comparison of methods to determine the dry matter losses during storage. Biomass Bioenerg. 96, 119, 2017.

10. MANZONE M., BALSARI P. Poplar woodchip storage in small and medium piles with different forms, densities and volumes. Biomass Bioenerg. 87, 162, 2016.

11. KRIGSTIN S., WETZEL S. A review of mechanisms responsible for changes to stored woody biomass fuels. Fuel. 175, 75, 2016.

12. CIVITARESE V., SPINELLI R., BARONTINI M., GALLUCCI F., SANTANGELO E., ACAMPORA A., SCARFONE A., DEL GIUDICE A. Open-Air Drying of Cut and Windrowed Short-Rotation Poplar Stems. Bioenerg Res. 8 (4), 1614, 2015.

13. PIETRYCZUK A., GÓRNIAK A.S., WIĘCKO A., CUDOWSKI A. Biomass and Abundance of Aquatic Fungi in a Polyhumic Dam Reservoir. Pol. J. Environ. Stud. 22 (3), 819, 2013.

14. HARTMANN H., REISINGER K., TUROWSKI P., ROSSMANN P. Handbuch Bioenergie - Kleinanlagen. Gülzow : Fachagentur Nachwachsende Rohstoffe e. V ISBN 3-00011041-0. 192, 2013.

15. BARONTINI M., CROGNALE S., SCARFONEA., GALLO P., GALLUCCI F., PETRUCCIOLI M., PESCIAROLI L., PARI L. Airborne fungi in biofuel wood chip storage sites Int. Biodeter. Biodegr. 90, 17, OSSN: 0964-8305, 2014.

16. ALAKOSKI E., JAMSEN M., AGAR D., TAMPIO E., WIHERSAARI M. From wood pellets to wood chips, risks of degradation and emissions from the storage of woody biomass - A short review. Renew. Sust. Energ. Rev. 54, 376, ISSN: 1364-0321, 2016.

17. NOLL M., JIRJIS R. Microbial communities in largescale wood piles and their effects on wood quality and the environment. Appl. Microbiol. Biot. 95 (3), 551, 2012.

18. MOKROŠ M., TABAČÁK M., LIESKOVSKÝ M., FABRIKA M. Unmanned aerial vehicle use for wood chips pile volume estimation. In: The International Archives of the Photogrammetry, Remote Sensing and Spatial Information Sciences, Volume XLI-B1, XXIII ISPRS Congress, 12-19 July 2016, Prague, Czech Republic,953, 2016.

19. TANG L., SHAO G. Drone remote sensing for forestry research and practices. J. For. Res. 26 (4), 791, 2015.

20. STN 56 0100, Microbiological examination of foodstuffs, articles of current use and environment of food establishments. Slovakian technical norm, 1988.

21. HOOG DE G.S., GUARRO J., GENÉ J., FIGUERAS M.J. Atlas of Clinical Fungi, Utrecht: Centralbureau voor Schimmelcultures, 1126, 2000.

22. YASSIN M.F., ALMOUQATEA S. I Assessment of airborne bacteria and fungi in an indoor and outdoor environment. Int. J. Environ. Sci. Tech. 7 (3), 535, 2010.

23. YAZDANI D., ZAINAL ABIDIN M.A., TAN Y.H., KAMARUZAMAN S. Evaluation of detection techniques of toxigenic Aspergillus isolates, Afr. J. Biotechnol. 9 (45), 7654, 2010.

24. FELŠÖCIOVÁ S., TANČINOVÁ D., RYBÁRIK L., MAŠKOVÁ Z., KAČÁNIOVÁ M. Mycobiota of Slovak Wine Grapes with emphasis on Aspergillus and Penicillium species in the small Carpathian Area. Potravinarstvo 9 (1), $501,2015$.

25. ISO $21527-2$. Microbiology of food and animal feeding stuffs. Horizontal method for the enumeration of yeasts and moulds. Part 2:Colony count technique in products with water activity less than or equal to $0,95, \mathbf{2 0 1 0}$.
26. STN EN ISO 7218. Microbiology of food and animal feeding stuffs. General requirements and guidance for microbiological examinations, 2014.

27. BENETT J. W. An overview of the genus Aspergillus. Eds. M. Machida, Gomi, K. Caister Academic Press. ISBN 9781-904455-53-0, 2010.

28. KROPACZ A., FOJUTOWSKI A. Colonization by fungi of wood chips stored in industrial conditions. Drewno 57 (193), 69, 2014.

29. GARSTANG J., WEEKES A., POULTER R., BARTLETT D. Identification and characterisation of factors affecting losses in the large-scale, non ventilated bulk storage of wood chips and development of best storage practises. London: First Renewables, 119, Ltd. for DTI. 2002.

30. BERGMAN Ö., NILSSON T. An experiment on outdoor storage of whole-tree chips. Upsala: The Swedish University of Agricultural Sciences, 109, 1979.

31. SZULC J., OTLEWSKA A., OKRASA M., MAJCHRZYCKA K., SULYOK M., GUTAROWSKA B. Microbiological Contamination at Workplaces in a Combined Heat and Power (CHP) Station Processing Plant Biomass. Int. J. Environ. Res. Public Health. 14 (1), 99, 2017.

32. GOŁOFIT-SZYMCZAK M., ŁAWNICZEK-WAŁCZYK A. Biomass as a source of biological hazards. Bezpiecz. Pr. 12, 17, 2011.

33. ŁAWNICZEK-WAŁCZYK A., GOŁOFIT-SZYMCZAK M., CYPROWSKI M., GÓRNY R. L. Exposure to harmful microbiological agents during the handling of biomass for power production purposes. Med. Pr., 63 (4), 395, 2012

34. MADSEN A.M. Identification of Work Tasks Causing High Occupational Exposure to Bioaerosols at Biofuel Plants Converting Straw or Wood Chips, Environmental Impact of Biofuels, Dr. Marco Aurelio Dos Santos Bernardes (Ed.), ISBN: 978-953-307-479-5, 2011.

35. LAITINEN S., LAITINEN J., FAGERNAS L., KORPIJARVI K., KORPINEN L., OJANEN K., AATAMILA M., JUMPPONEN M., KOPONEN H., JOKINIEMI J. Exposure to biological and chemical agents at biomass power plants. Biomass Bioenerg. 93, 78, 2016.

36. OSTRÝ V., MALÍŘ F., TOMAN J., GROSSE Y. Mycotoxins as human carcinogens-the IARC Monographs classification. Mycotoxin Res. 33 (1), 65, 2017.

37. SHOHAM S. Host/Pathogen Interactions in Fungal Keratitis. Curr. Fungal Infect. Rep. 9 (1), 52, 2015.

38. KAUSHAL R., SHARMA N., TANDON D. Cellulase and xylanase production by co-culture of Aspergillus niger and Fusarium oxysporum utilizing forest waste. Turk. J. Biochem. 37 (1), 35, 2012.

39. KYMÄLÄINEN M., MÄKELÄ M.R., HILDÉN K., KUKKONEN J. Fungal colonisation and moisture uptake of torrefied wood, charcoal, and thermally treated pellets during storage. Eur. J. Wood Prod. 73, 709, 2015.

40. BAXI S.N., PORTNOY J.M., LARENAS-LINNEMANN D., PHIPATANAKUL W. Exposure and Health Effects of Fungi on Humans. J. Allergy. Clin. Immun. 4 (3), 396, 2016.

41. ISMAIEL A.A., PAPENBROCK J. Mycotoxins: Producing Fungi and Mechanisms of Phytotoxicity. Agriculture 5 (3), 492, 2015.

42. JAIN S., ISHWAR B., RAKESH M., JAIN S., CHUGH T. D. Pantoea agglomerans infection behaving like a tumor after plant thorn injury: An unusual presentation. Indian J. Pathol. Micr. 55 (3), 386, 2012.

43. BADIEE P. Mycotic Keratitis, a State-of-the-Art Review. Jundishapur J.Microbiol. 6 (5), e8561, 2013. 
44. CHAKRABARTI A., SINGH R. The emerging epidemiology of mould infections in developing countries. Curr. Opin. Infect. Dis. 24 (6), 521, 2011.

45. GOMES M.Z.R., LEWIS R.E., KONTOYIANNIS D.P. Mucormycosis Caused by Unusual Mucormycetes, Non-Rhizopus, -Mucor, and -Lichtheimia Species. Clin. Microbiol. Rev. 24 (2), 411. 2011.

46. DA ROCHA M.E.B., FREIRE F.D.O., MAIA F.B.F., GUEDES M.I.F., RONDINA D. Mycotoxins and their effects on human and animal health. Food Control 36 (1), 159, 2014.

47. NEVALAINEN A., TÄUBEL M., HYVÄRINEN A. Health effects of fungi, bacteria, and other bioparticles. In: Synergic Influence of Gaseous, Particulate, and Biological Pollutants on Human Health, Ed. Pastuszka J. S., Taylor \& Francis, London, pp. 303, ISBN 978-1-4987-1512-6, 2015.

48. MARIN S., RAMOS A.J., CANO-SANCHO G., SANCHIS V. Mycotoxins: Occurrence, toxicology, and exposure assessment. Food Chem. Toxicol. 60, 218, 2013.

49. NIELSEN K. F. MOGENSEN MØLGAARD J., JOHANSEN M., LARSEN T. O., FRISVAD J. CH. Review of secondary metabolites and mycotoxins from the Aspergillus niger group. Anal. Bioanal. Chem. 395, 1225, 2009.
50. MÄKELÄA M.R., DONOFRIOB N., DE VRIES R.P. Plant biomass degradation by fungi. Fungal Genet. Biol. 72, 2, 2014.

51. SULEYMAN G., ALANGADEN G.J. Nosocomial Fungal Infections: Epidemiology, Infection Control, and Prevention. Infect. Dis. Clin. N. Am. 30 (4), 1023, 2016.

52. ROHR A.C., CAMPLEMAN S.L., LONG CH.M., PETERSON M.K., WEATHERSTONE S., QUICK W., LEWIS A. Potential Occupational Exposures and Health Risks Associated with Biomass-Based Power Generation. Int. J. Env. Res. Pub. He. 12 (7), 8542, 2014.

53. MULLEROVA J. Health and safety hazards of biomass storage. In: $14^{\text {th }}$ International Multidisciplinary Scientific Geoconference (SGEM), Jun 17-26, Albena Bulgaria. 2014.

54. YODER A.M., SCHWAB C., GUNDERSON P., MURPHY D. Safety and Health in Biomass Production, Transportation, and Storage: A Commentary Based on the Biomass and Biofuels Session at the 2013 North American Agricultural Safety Summit. J. Agromed. 19 (2), 83, 2014. 